tical, economic, and social problems which were to be found in the countries of the West, and he had very great doubts whether it was wise to bring the same problems into China by the introduction of Western science and methods. The Chinese now see that they cannot isolate themselves from the other countries of the world, and they are anxious to accept from them sufficient, at least, to preserve their national integrity, but the forces behind them will make it impossible to draw a limiting line.

For many years I have been watching with interest the great evolution which is going on in the countries bounded by the Pacific area. Japan led the way, and now China follows, probably, however, at a slower rate; but, as my Chinese friend sometimes said to me, "I wonder where you people of the West think you will be as regards trade and industry, as well as other things, when China is fully awake?" This opens up a wide vista for speculation, and I merely mention it in the hope that those who are proposing what seem to be small things may consider their future possibilities and their results on the civilisation of the world.

Henry Dyer.

\section{THE ROYAL SOCIETY OF ARTS AND THE LONDON INSTITUTION.}

T N Nature of April 6, I905, attention was directed to negotiations that had commenced between the Society of Arts and the London Institution having for their object the amalgamation of the two institutions. A special meeting of the promoters of the London Institution was about to be held to consider the scheme, which was supported by a joint committee of the two institutions; and whilst it was recognised that some opposition on the part of members of the London Institution would have to be reckoned with, it was assumed that amalgamation would be brought about. This expectation was not realised. Whilst there is reason to believe that the members of the Society of Arts would have been practically unanimous in their support of amalgamation, a vigorous minority of the London Institution opposed, with the result that the scheme was never voted upon. It was shelved, and for the time being no more was heard of amalgamation. After the failure to bring about union between the two institutions, no attempt was made to vitalise the London Institution. It remained, as it had been for some years, practically moribund.

Impressed with the undesirability of allowing matters to continue as they are, and as convinced as ever that amalgamation would be for the advantage of both institutions, those members of the London Institution who moved in the matter in 1905 have now renewed their efforts to bring about an amalgamation of the two institutions. They first tested the feeling of members by means of a postcard ballot, which resulted in 526 supporting the proposal for amalgamation and 84 voting against, some 400 remaining neutral. This was a sufficiently decisive vote to warrant the managers of the London Institution in approaching the Royal Society of Arts, but before that could be done certain members of the institution, strong opponents of amalgamation, moved in opposition, with the result that there was a special meeting of members of the institution, and a ballot taken. This ballot resulted in 322 voting in favour of amalgamation, and 218 against it, leaving between 400 and 500 who preferred to be neutral. The managers of the London Institution did not consider that this vote was sufficiently decisive to warrant them in approaching the Royal Society of Arts without further consideration, and accordingly a meeting was arranged for March to to consider the position. The result of that meeting has not been made known to the public, but it is understood that it disclosed considerable hesitation in proceeding with the scheme unless, and until, the minority, or some of them, could be induced to waive their opposition.

So the matter stands. It would be rash to predict the upshot. There is no reason to suppose that the members of the Royal Society of Arts are not as willing as they were three years ago to support a scheme of amalgamation approved by the secretary, Sir Henry T. Wood, and the committee. Nor do the arguments of the minority of the London Institution seem very convincing. One of their objections is that, under the proposed scheme, the institution would be moved from the City to somewhere "east of Charing Cross and west of Chancery Lane." We can understand this objection having considerable weight fifty years ago. Founded in 1805 by merchants and bankers of the City of London, the object of the London Institution was to maintain, in what was then a central position, an extensive general library of reference, and to promote the diffusion of knowledge by lectures and conversazioni; for at that time, and for many years afterwards, the City contained a large residential population. This population has now practically disappeared, and the number of proprietors who use the institution is small, and every year becomes smaller. To remove the institution to a building just outside the City boundaries, at or near the east end of the Strand, would not be inconsistent with the objects for which the institution is intended. The dissentient minority urge again that the Corporation of the City of London ought to take action to amalgamate the institution with the Gresham Trust. But whatever may be said in favour of this proposal, it means that the Corporation would have to endow the London Institution, and that, there is good reason for believing, they would not do.

The arguments in favour of amalgamation seem to us very strong, and we hope that in the end they will prevail. The history of the Royal Society of Arts has been a highly creditable one. It is under sagacious control. Its financial position is sound, and its services to the community great. Amalgamation with the London Institution would mean for it some sacrifice of sentiment, but the union would be advantageous to it in certain ways. It would give it the permanent local building that it lacks. The site of the London Institution is estimated to be worth at least I50,oool., and this would be amply sufficient to provide an adequate building, and might, indeed, supply accommodation for several other societies disposed to join in the scheme of building. The library of the London Institution, joined to that of the Royal Society of Arts, would make one of the best reference libraries in the metropolis, and the combined revenues would enable much more to be done in the interests of science, and provide a better knowledge of scientific work and methods than is possible at present. On the whole, the arguments seem greatly in favour of amalgamation between the two institutions on terms equitable to both, and it may be hoped that when the dissentient minority of the London Institution realise more fully than they seem to do at present that the Corporation of London is not prepared to subsidise their institution, their objections to amalgamation with the Royal Society of Arts will not continue to be pressed. 